\title{
Enhancing lithium leaching by mechanical activation
}

\author{
Nader Setoudeh ${ }^{1,2 *}$, Ataollah Nosrati ${ }^{2}$, Nicholas J. Welham ${ }^{2,3}$ \\ ${ }^{1}$ Materials Engineering Department, Yasouj University, Yasouj, 75918-74831, Iran \\ ${ }^{2}$ Edith Cowan University, School of Engineering, Chemical Engineering Department, Perth, Australia, \\ ${ }^{3}$ Welham Metallurgical Services, South Lake, Australia \\ *Corresponding author: nsetoudeh@yu.ac.ir, ORCID ID:0000-0003-0138-2533
}

Received: 26 February 2019; revised:26 February; accepted: 28 February 2019

\begin{abstract}
The lithium ( $\mathrm{Li}$ ) bearing minerals lepidolite and spodumene were mixed with different mass ratios of $\mathrm{Na}_{2} \mathrm{SO}_{4}$ and mechanically activated by milling in a planetary ball mill for $5 \mathrm{~h}$. The milled samples were studied using thermogravimetry under an air atmosphere up to $950^{\circ} \mathrm{C}$. Isothermal heating of the milled samples was undertaken in a furnace at temperatures of $700^{\circ} \mathrm{C}$ and $800^{\circ} \mathrm{C}$ for $1 \mathrm{~h}$. Hot water leaching of the calcines indicated that increasing the calcination temperature had a significant effect on the dissolution of lithium. The leaching of lithium from lepidolite was notably higher than that from spodumene.
\end{abstract}

Keywords: Lithium, Mechanical activation, Calcine, Lepidolite, Milling, Spodumene

\section{INTRODUCTION}

Lithium is produced from variety of natural mineral sources. The most abundant lithium containing rocks/ minerals are pegmatites, such as spodumene and petalite. Other lithium minerals which are commercially mined include lepidolite, amblygonite, zinnwaldite and eucryptite [1]. Processes to produce lithium compounds include calcination followed by acid leaching, alkaline leaching, chlorination and direct leaching using hydrofluoric acid (HF) [1-4]. The major drawbacks of these processes are high energy consumption, high reagent consumptions and complex purification processes. The low inherent acid reactivity of natural $\alpha$-spodumene, necessitates conversion to the more reactive and leachable form ( $\beta$-spodumene) at higher temperature [1]. Conversion of $\alpha$-spodumene to $\beta$-spodumene by roasting at $1070-1100{ }^{\circ} \mathrm{C}$ for processing of spodumene is also reported $[1,5,6]$.

Due to these problems, roasting of lithium ore minerals such as lepidolite with sodium sulphate $\left(\mathrm{N}_{2} \mathrm{SO}_{4}\right)$ followed by water leaching is indicated in literature [57]. Sulphation roasting of $\alpha$-spodumene with sodium sulphate $\left(\mathrm{Na}_{2} \mathrm{SO}_{4}\right)$ may be an alternative route for lithium extraction from $\alpha$-spodumene concentrate in order to eliminate the necessity to undertake the energy intensive $\alpha \rightarrow \beta$ phase transition in the spodumene concentrates.
Previous publications showed that mechanical activation and mechanical milling have beneficial effects on the leaching of solid phases in minerals and ore concentrates [8-11]. These investigations indicated significant effects of mechanical activation processes for multiphase systems such as $\mathrm{MoS}_{2}-\mathrm{Mg}$ [12], carbothermic reduction reaction [13] and metallothermic reduction of metal sulphide [14-15].

Sulphation roasting of lepidolite ore and spodumene concentrate with $\mathrm{Na}_{2} \mathrm{SO}_{4}$ was investigated after milling the mixtures using a planetary ball mill. After isothermal heating the as-milled mixtures of lepidolite $+\mathrm{Na}_{2} \mathrm{SO}_{4}$ and spodumene $+\mathrm{Na}_{2} \mathrm{SO}_{4}$, were leached in hot water.

\section{EXPERIMENTAL}

The starting materials were a lepidolite ore ( $\mathrm{Li} \sim 0.68 \%$ ) and a spodumene concentrate ( $\mathrm{Li} \sim 2.63 \%$ ) and high purity sodium sulphate $\left(\mathrm{Na}_{2} \mathrm{SO}_{4}\right)$. The chemical composition for each concentrate is listed in Table 1. Figure 1 and 2 show the X-ray diffraction (XRD) analyses for lepidolite and spodumene concentrates, respectively. Figure 1 shows that the lepidolite concentrate contains lepidolite (JCPDS 76-0535), quartz (JCPDS 87-2096), muscovite (JCPDS 007-0042) and albite (JCPDS 9-0466) phases. Pure lepidolite contains $\sim 3.6 \% \mathrm{Li}$, so the ore contains around $18 \%$ lepidolite. There is one peak at $2 \theta \sim 14^{\circ}$ in lepidolite ore concentrate which is 
Table 1. Chemical composition of spodumene and lepidolite concentrates by ICP analysis.

\begin{tabular}{llllllllll}
\hline Sample & $\mathrm{Al}_{2} \mathrm{O}_{3}$ & $\mathrm{CaO}$ & $\mathrm{Fe}_{2} \mathrm{O}_{3}$ & $\mathrm{~K}_{2} \mathrm{O}$ & $\mathrm{MgO}$ & $\mathrm{MnO}$ & $\mathrm{Na}_{2} \mathrm{O}$ & $\mathrm{SiO}_{2}$ & $\mathrm{Li}_{2} \mathrm{O}$ \\
\hline Spodumene & 23.06 & 0.47 & 1.06 & 0.75 & 0.28 & 0.07 & 0.73 & 66.94 & 5.64 \\
Lepidolite & 19.53 & 0.01 & 0.30 & 4.28 & 0.26 & 0.11 & 1.08 & 68.29 & 1.46 \\
\hline
\end{tabular}

unidentified, but the width suggests it may be a clay group mineral. Figure 2 shows that the spodumene concentrate is predominantly spodumene (JCPDS 330786) with lesser amount of quartz (JCPDS 87-2096), while several weak peaks are related to unidentified minor impurities. Pure spodumene contains $\sim 3.7 \% \mathrm{Li}$, so the concentrate contains $\sim 71 \%$ spodumene, the majority of the rest being quartz.

Mixtures of the lepidolite $+\mathrm{Na}_{2} \mathrm{SO}_{4}$ and spodumene+ $\mathrm{Na}_{2} \mathrm{SO}_{4}$ were prepared with two different mass ratios of $1: 0.5$ and $1: 1$. These mixtures were mechanically milled in a closed chamber using a planetary ball mill (PMQW series Planetary Ball Mill) for $5 \mathrm{~h}$. The milling conditions for all samples were: rotation speed of $600 \mathrm{rpm}$, zirconia milling chamber, zirconia balls and the ball-to-powder

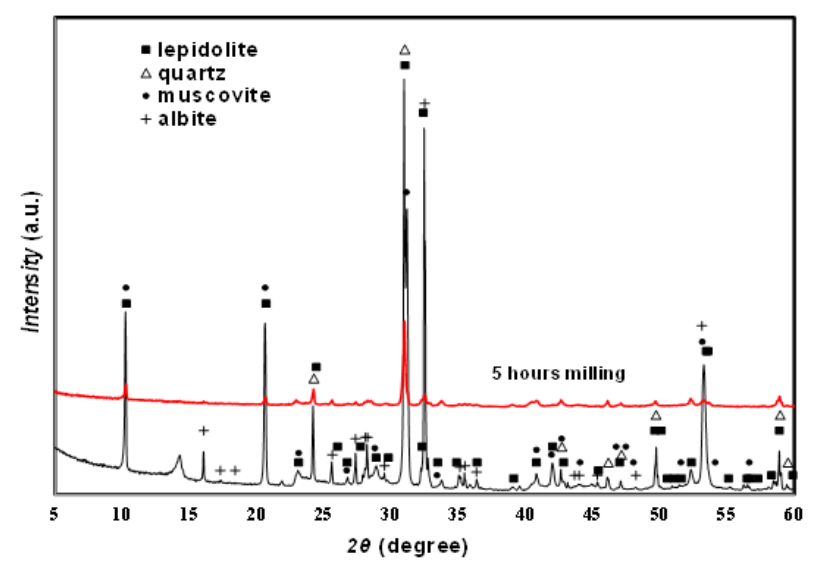

Fig. 1. XRD pattern of lepidolite concentrate (as starting material) and the lepidolite concentrate after $5 \mathrm{~h}$ milling.

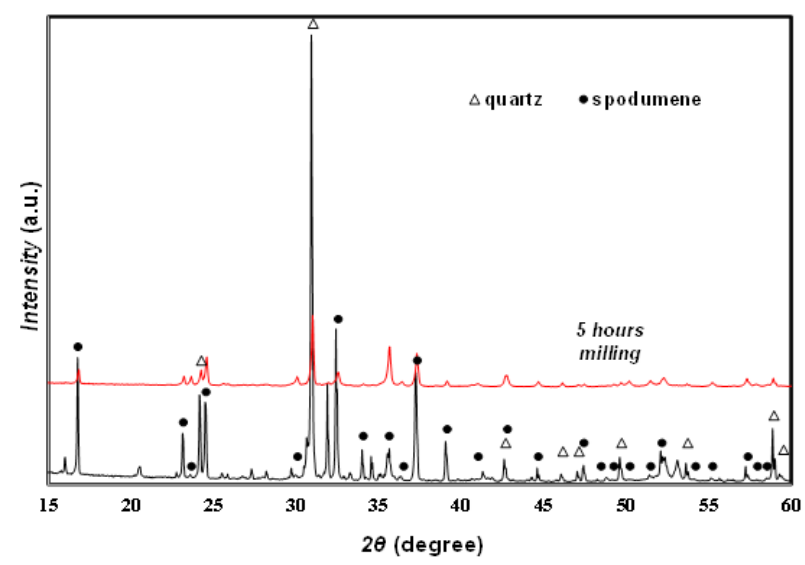

Fig. 2. XRD pattern of spodumene concentrate (as starting material) and the spodumene concentrate after $5 \mathrm{~h}$ milling. weight ratio of 20:1. After finishing milling, each of the 5 $\mathrm{h}$ milled mixtures of lepidolite $+\mathrm{Na}_{2} \mathrm{SO}_{4}$ and spodumene concentrate $+\mathrm{Na}_{2} \mathrm{SO}_{4}$ were poured into ceramic crucible, then placed in a muffle furnace and heated at $700{ }^{\circ} \mathrm{C}$ or $800{ }^{\circ} \mathrm{C}$ for $1 \mathrm{~h}$. The furnace was turned off after 1 $\mathrm{h}$ and the samples in the crucible cooled to ambient temperature $\left(\sim 25^{\circ} \mathrm{C}\right)$. The calcined samples were stored in sealed containers for further experiments and/ or characterization.

The calcines were subjected to agitated deionized water leaching at a slurry density of $40 \mathrm{~g} \cdot \mathrm{L}^{-1}$ at $80^{\circ} \mathrm{C}$ for $1 \mathrm{~h}$. After the required time, the slurry was filtered and the solution analysed by MPAES. The solid residue was dried at $120^{\circ} \mathrm{C}$ for $2 \mathrm{~h}$.

Thermogravimetric analysis (TGA) was carried out on the milled mixtures of lepidolite $+\mathrm{Na}_{2} \mathrm{SO}_{4}$ and spodumene $+\mathrm{Na}_{2} \mathrm{SO}_{4}$ with different mass ratios at the heating rate of $10^{\circ} \mathrm{C} \cdot \mathrm{min}^{-1}$ up to $950^{\circ} \mathrm{C}$ under flowing air using a thermogravimetric analyser (Perkin Elmer -4000). The samples were held at $950{ }^{\circ} \mathrm{C}$ for one minute then cooled to room temperature with cooling rate of $50^{\circ} \mathrm{C} \cdot \mathrm{min}^{-1}$ under flow of atmospheric air.

All solid products were analysed using XRD ( $\mathrm{Co}-\mathrm{K \alpha}$ radiation, $40 \mathrm{kV}, 40 \mathrm{~mA}$ ) over a $2 \theta$ range of $5-60^{\circ}$ for every $0.026^{\circ}$ step. Lithium analysis of the leaching liquors were carried out using MP-AES (Agilent Technologies 4200).

\section{RESULTS AND DISCUSSION}

XRD results: The XRD traces of lepidolite concentrate before and after $5 \mathrm{~h}$ milling is shown in Figure 1 , where the signs of two peaks in $2 \theta \sim 14^{\circ}$ and $2 \theta \sim 16^{\circ}$ (albite phase) are disappeared in the $5 \mathrm{~h}$ milled sample. Decreasing in peak intensities and peak broadening of the major peaks of lepidolite phase (such as $2 \theta \approx 10.3^{\circ}$, $20.7^{\circ}$ and $32.4^{\circ}$ ) indicates that ball milling has significant role in refining both particle size and crystallite size in the activated lepidolite concentrate. Although the intensities of major peaks for quartz phase (such as $2 \theta \approx 24.2^{\circ}$ and $\left.31^{\circ}\right)$ are decreased, the signs of quartz $\left(\mathrm{SiO}_{2}\right)$ phase are not completely disappeared after $5 \mathrm{~h}$ milling (Figure 1). The XRD patterns of spodumene concentrate before and after $5 \mathrm{~h}$ milling are also indicated in Figure 2. As for lepidolite, the intensities of the spodumene peaks are decreased and broadened after $5 \mathrm{~h}$ milling. The intensities of major peaks for quartz phase are also decreased.

Figure 3 shows the XRD patterns for lepidolite $+\mathrm{Na}_{2} \mathrm{SO}_{4}$ after TGA analysis for mass ratios of $1: 0.5$ and $1: 1$ and after milling. The traces of lepidolite and $\mathrm{Na}_{2} \mathrm{SO}_{4}$ phases are clearly observed in the milled mixtures 


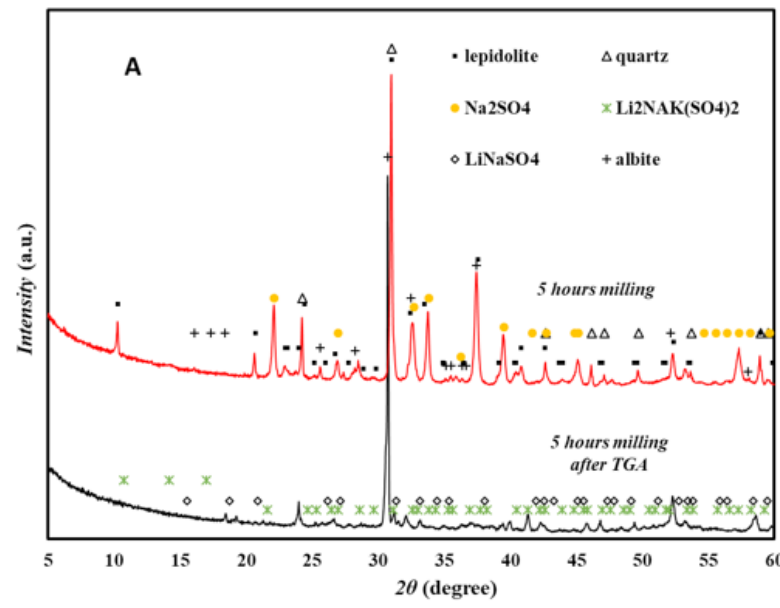

- lepidolite $\Delta$ quartz $\bullet \mathrm{Na2SO4} \triangle \mathrm{LiKSO4} \times$ Li2NaK(SO4)2 $\diamond$ LiNaSO4 + albite

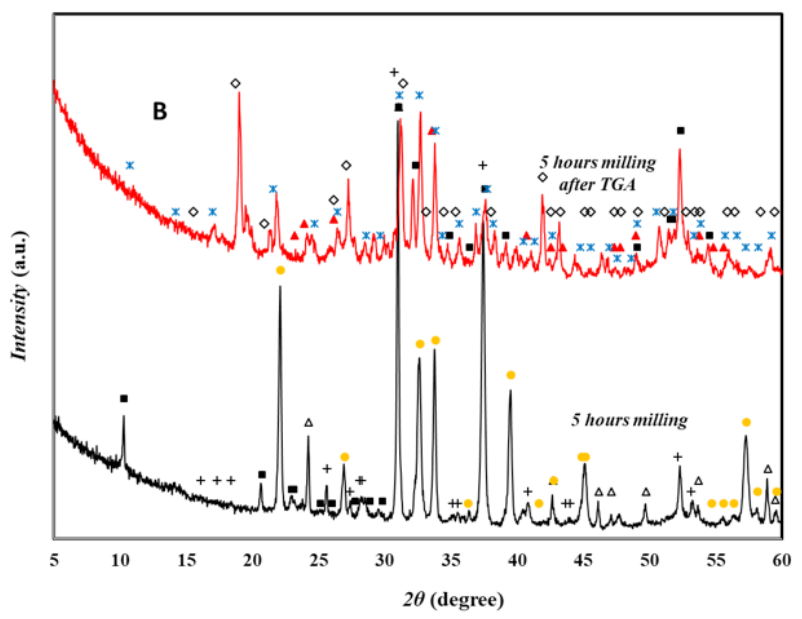

Fig. 3. XRD patterns of TGA solid residues for lepidolite$-\mathrm{Na}_{2} \mathrm{SO}_{4}$ mixtures with mass ratios of $1: 0.5(\mathrm{~A})$ and $1: 1(B)$

for both mass ratios suggesting minimal reaction occurrence. As expected, the $\mathrm{Na}_{2} \mathrm{SO}_{4}$ peaks are relatively more intense for the mass ratio $1: 1$ sample (Figure $3 \mathrm{~A}$ ) than the 1:0.5 ratio sample (Figure 3B). The traces of starting materials are no longer present after TGA analysis implying reactive consumption of both phases occurred during heating. This is supported by the presence of peaks for new phases such as $\mathrm{LiNaSO}_{4}$ and $\mathrm{Li}_{2} \mathrm{NaK}\left(\mathrm{SO}_{4}\right)_{2}$ in the residue of the $1: 1$ mass ratio sample.

The XRD traces of the TGA residues for spodumene $+\mathrm{Na}_{2} \mathrm{SO}_{4}$ mixtures with different mass ratios are indicated in Figure 4. The peaks for spodumene and $\mathrm{Na}_{2} \mathrm{SO}_{4}$ are clearly observed in $5 \mathrm{~h}$ milled mixtures for both mass ratios, with no new peaks indicating no reaction occurred during milling. The peaks for $\mathrm{LiNaSO}_{4}$ are observed in the TGA residue of both mass ratios. However, in both residue samples the presence of unreacted spodumene and quartz indicate that reaction is incomplete for both mass ratios.

The chemical analysis of as received concentrates in Table 1 shows that some oxides such $\mathrm{K}_{2} \mathrm{O}$ are present
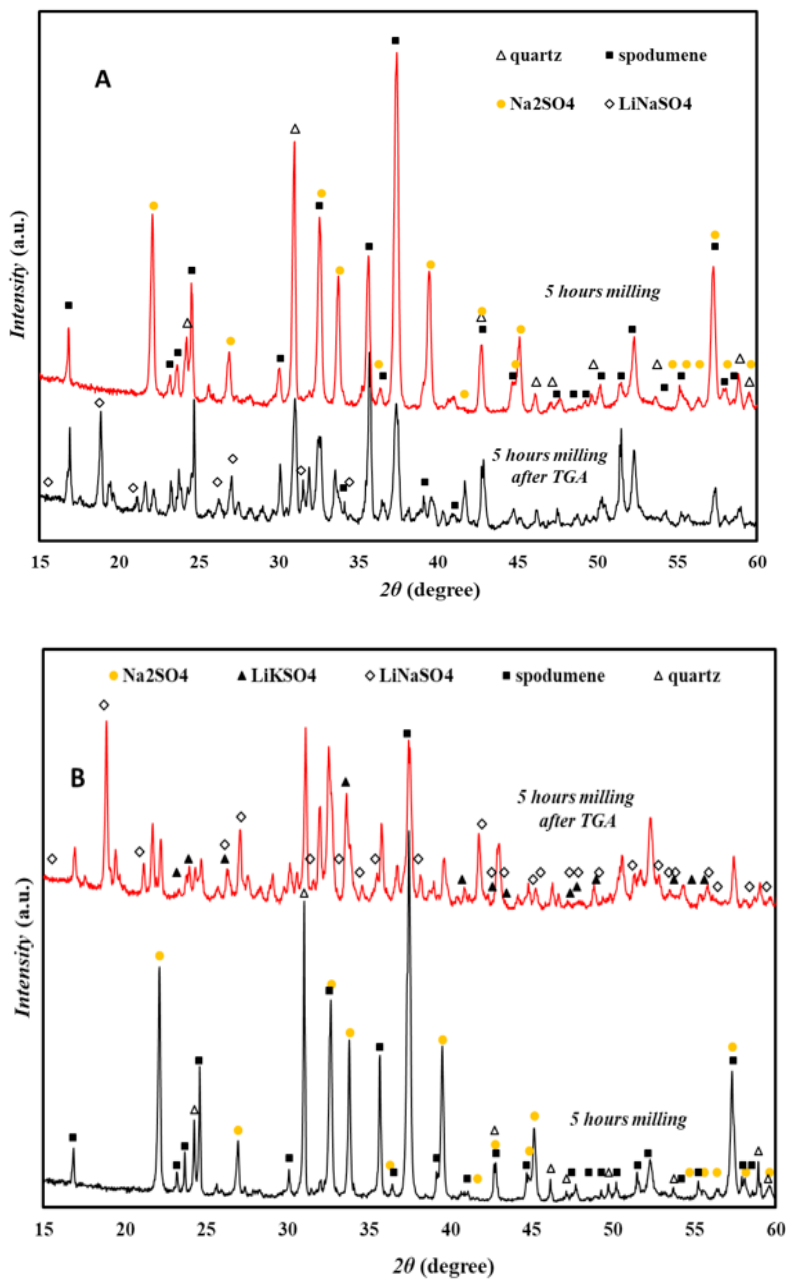

Fig. 4. XRD patterns of TGA solid residues for spodumene$-\mathrm{Na}_{2} \mathrm{SO}_{4}$ mixtures with mass ratios of $1: 0.5(\mathrm{~A})$ and $1: 1(\mathrm{~B})$

in spodumene concentrate as impurities. Therefore, it is reasonable to observe the presence of other lithium phases such as $\mathrm{LiKSO}_{4}$ and $\mathrm{Li}_{2} \mathrm{NaK}\left(\mathrm{SO}_{4}\right)_{2}$ in the XRD analysis of lepidolite $+\mathrm{Na}_{2} \mathrm{SO}_{4}$ and spodumene $+\mathrm{Na}_{2} \mathrm{SO}_{4}$ mixtures (Figure 3 and 4).

Water leaching results: In light of the above results, isothermal heating of milled mixtures at 700 and 800 ${ }^{\circ} \mathrm{C}$ was undertaken for $1 \mathrm{~h}$ prior to hot water leaching. Figure $5 \mathrm{~A}$ and $5 \mathrm{~B}$ show the concentration of leached lithium in solution from milled mixtures after $1 \mathrm{~h}$ isothermal heating at different temperatures.

Figure 5 shows that for both samples the concentration of lithium in solution was increased by calcination at $700^{\circ} \mathrm{C}$ and increased further by heating at $800^{\circ} \mathrm{C}$. The lithium concentration achieved from lepidolite (Figure $5 A$ ) is lower than expected given the apparently high extent of reaction indicated by XRD. Clearly, there are other water-insoluble phases remaining in the residue which contain lithium which remain unidentified. The higher extraction at $800{ }^{\circ} \mathrm{C}$ shows that the reaction to produce soluble phases is enhanced by higher calcination temperature. The similarity between the 
XRD traces after calcination would suggest this is due to slower kinetics at $700{ }^{\circ} \mathrm{C}$ rather than a change in the suite of products.

Similar results were obtained for spodumene, however, the concentrations of leached lithium were notably lower, despite the significantly higher starting concentration of $\mathrm{Li}$ in the spodumene. This, coupled with the lower extent of reaction indicated by XRD suggest that spodumene is much less amenable to sulphation than lepidolite. In order for spodumene to be rendered leachable it has to undergo a thermal crystal transformation from $\alpha$-spodumene to $\beta$-spodumene [1]. The phase transition requires temperatures of $\sim 900$ ${ }^{\circ} \mathrm{C}$ or higher to occur with appreciable rates $[1,5-6]$. These results suggest that the sulphation reaction may only occur after transformation to $\beta$-spodumene and a higher calcination temperature may be expected to give better lithium extractions.
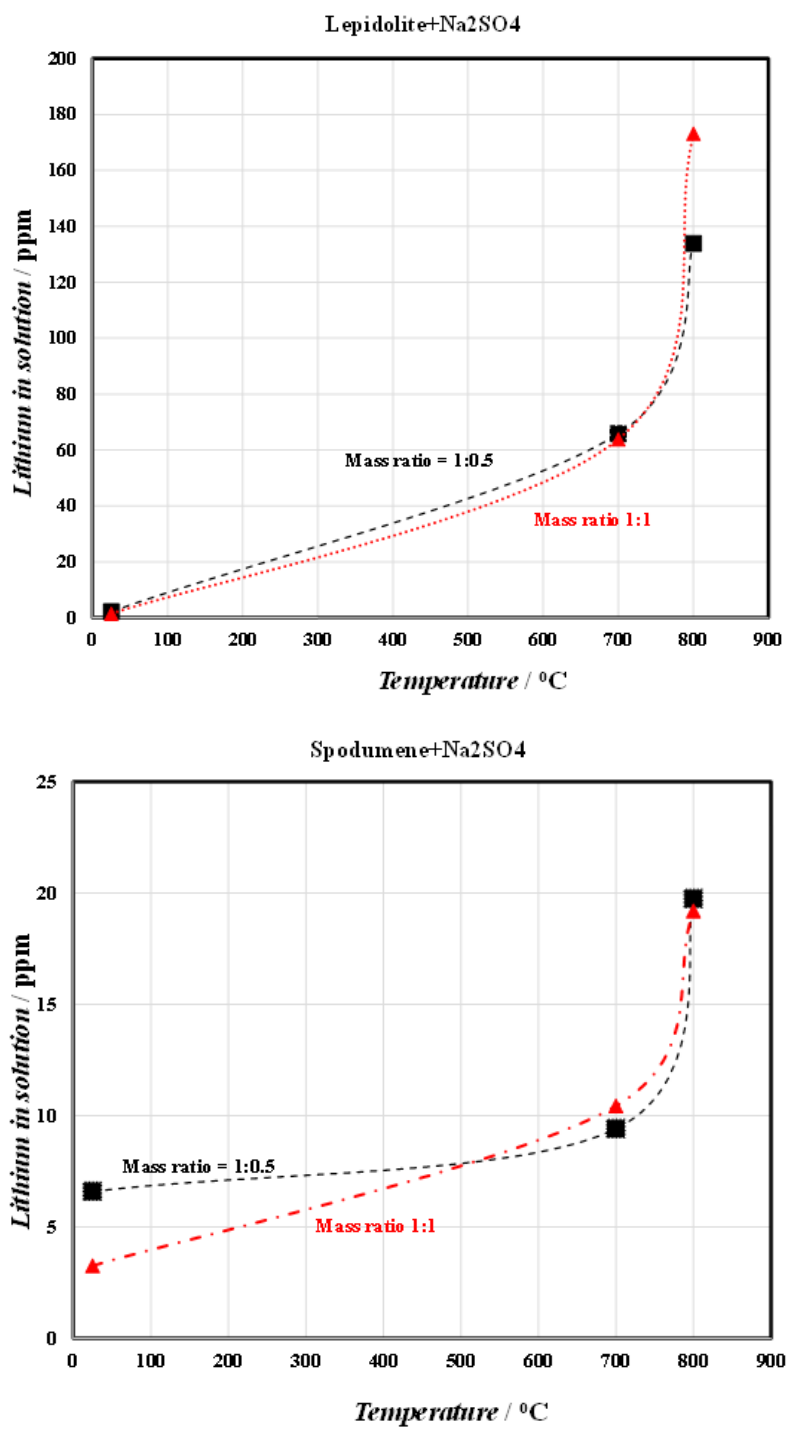

Fig. 5. Concentration of lithium (ppm) in the liquor solutions after leaching in hot water at $80^{\circ} \mathrm{C}$ for $1 \mathrm{~h}$ as a function of the calcination temperature.
It is interesting to note that having a higher mass ratio of $\mathrm{Na}_{2} \mathrm{SO}_{4}$ to either lepidolite or spodumene did not result in substantially higher lithium extractions. Clearly, the extraction of lithium is not being limited by the amount of $\mathrm{Na}_{2} \mathrm{SO}_{4}$. The lower the ratio which leads to lithium extraction the more cost effective the process as less $\mathrm{Na}_{2} \mathrm{SO}_{4}$ is required and the mass of lithium mineral present during milling is higher. It is expected that further refinement of the $\mathrm{Na}_{2} \mathrm{SO}_{4}$ addition prior to milling is possible.

\section{CONCLUSIONS}

Mechanical activation using planetary milling was used to investigate the effect on lithium leaching of mixtures of spodumene or lepidolite and $\mathrm{Na}_{2} \mathrm{SO}_{4}$ Milling of lepidolite and spodumene concentrate result in refinement of both particle and crystallite sizes. After milling with $\mathrm{Na}_{2} \mathrm{SO}_{4}$ and heating to $950{ }^{\circ} \mathrm{C}, \mathrm{XRD}$ showed peaks for new phases such as $\mathrm{LiNaSO}_{4}$, $\mathrm{LiKSO}_{4}$ and $\mathrm{Li}_{2} \mathrm{NaK}\left(\mathrm{SO}_{4}\right)_{2}$ in both systems. Lepidolite was absent from the XRD whilst spodumene remained, indicating differing extents of reaction for the two minerals. The amount of lithium leached after $1 \mathrm{~h}$ from the lepidolite $+\mathrm{Na}_{2} \mathrm{SO}_{4}$ calcines using hot water was notably higher than for spodumene $+\mathrm{Na}_{2} \mathrm{SO}_{4}$ calcines. Both minerals showed significant increases in lithium extraction at $800^{\circ} \mathrm{C}$ compared with $700{ }^{\circ} \mathrm{C}$ suggesting even higher calcination temperatures will lead to increased recoveries.

\section{ACKNOWLEDGMENT}

This research work has formed a part of a research project entitled Lithium Ore Processing being undertaken by Nader Setoudeh as a visiting academic on sabbatical leave at Edith Cowan University. The authors gratefully acknowledge the Deputy of Research and Technology of Yasouj University, Edith Cowan University (ECU) and Welham Metallurgical Services for their ongoing financial and in-kind support of the research project. The authors also gratefully acknowledge Dr. Guanlian Zhou for his generous cooperation in the Chemical Engineering laboratory of ECU.

\section{REFERENCES}

1. Welham N.J., Nosrati A., Setoudeh N., (2017) Lithium ore processing: an overview of the current and new processes. Metallurgical Plant Design and Operating Strategies - World's Best Practice (MetPlant 2017) 11-12 September 2017, Perth WA 185-194.

2. Yan Q, Li X, Wang Z, Wang J, Guo H, et.al (2012) Extraction of lithium from lepidolite using chlorination roasting-water leaching process. Trans. Nonferrous Met. Soc. China., 22(7),17531759. doi:10.1016/S1003-6326(11)61383-6

3. Barbosa L.I., Valente G., Orosco R.P., Gonzalez J.A. (2014) Lithium extraction from $\beta$-spodumene through chlorination with chlorine gas, Miner. Eng., 
56, 29-34.doi:10.1016/j.mineng.2013.10.026

4. Rosales G.D., Ruiz M.C., Rodriguez M.H. (2016) Study of the extraction kinetics of lithium by leaching $\beta$-spodumene with hydrofluoric acid, Minerals., 6(98), 1-12. doi:10.1016/j.hydromet.2014.04.009

5. Chen Y., Tian Q., Chen B., Shi X., Liao T. (2011) Preparation of lithium carbonate from spodumene by a sodium carbonate autoclave process, Hydrometal., 109, 43-46. doi:10.1016/j. hydromet.2011.05.006

6. Luong V.T., Kang D.J., An J.W., Kim M.J, Tran T. (2013) Factors affecting the extraction of lithium from lepidolite, Hydrometal., 134-135, 54-61. doi:10.1016/j.hydromet.2013.01.015

7. Vieceli N, Nogueira C.A., Pereira M.F.C., Durao F.O et.al. (2017) Optimization of lithium extraction from Lepidolite by roasting using sodium and calcium sulfates. Mineral Processing and Extractive Metallurgy Review., 38(1), 62-72. doi:10.1080/08 $\underline{827508.2016 .1262858}$

8. Welham N.J. (2001) Enhanced dissolution of tantalite/columbite following milling. Inter. J. Miner. Processing, 61(3), 145-154. doi:10.1016/S03017516(00)00032-6

9. Zhang Y., Zheng S., Du H.H., Xu H., Zhang Y. (2010) Effect of mechanical activation on alkali leaching of chromite ore. Trans. Nonferrous Met. Soc. China, 20(5), 888-891. doi:10.1016/S10036326(09)60231-4
10. Vieceli N., Nogueira C.A., Pereira M.F.C, Paula Soares Dias A., et.al. (2017) Effects of mechanical activation on lithium extraction from a lepidolite ore concentrate, Miner. Eng., 102, 1-14. doi:10.1016/j. mineng.2016.12.001

11. Vieceli N., Nogueira C.A., Pereira M.F.C., Durao F.O et.al. (2018) Recovery of lithium carbonate by acid digestion and hydrometallurgical processing from mechanically activated lepidolite, Hydrometal., 175, 1-10. doi:10.1016/j.hydromet.2017.10.022

12. Temuujin J., Setoudeh N., Welham N.J. (2015) Comparative study of mechanical activation of molybdenite $\left(\mathrm{MoS}_{2}\right)$ with and without magnesium (Mg) addition, Mongolian J. Chemistry., 16(42), 3033. doi:10.5564/mjc.v16i0.666

13. Setoudeh N., Ali Askari Zamani M., Welham N.J (2011) Carbothermic reduction of mechanically activated mixtures of celestite and carbon. Proceedings of World Academy Sci. Eng. and Tech., 74, 531-534.

14. Takacs L., Balaz P., Torosyan A.R (2006) Ball milling-induced reduction of $\mathrm{MoS}_{2}$ with Al. J. Mater. Sci., 41, 7033-7039. doi:10.1007/s10853-0060950-6

15. Setoudeh N, Welham N. J. (2017) Metallothermic reduction of zinc sulfide induced by ball milling. J. Mater Sci., 52, 6388-6400. doi:10.1007/s10853017-0873-4 